\title{
GENDER INEQUALITY BELOW THE ,GLASS CEILING“ - CASE STUDY: THE HOTEL INDUSTRY IN VOJVODINA (SERBIA)
}

\author{
DOI: https://doi.org/10.18509/AGB.2021.18 \\ UDC: $305-055.2: 640.4(497.113)]: 303.62$ \\ 316.647.82-055:640.4(497.113)]:303.62
}

Vuk Garača, Svetlana Vukosav, Danka Curaković, Milan Bradić

\author{
University of Novi Sad, Faculty of Sciences, Tourism and Hotel Management, Trg Dositeja Obradovića 3, 21000 \\ Novi Sad, Serbia
}

corresponding author: vuk garaca@yahoo.com

submitted: 29.05 .2020

accepted: 28.08 .2020

published: 25.10 .2020

\begin{abstract}
Gender inequality is a common and modern subject in the hotel industry. The citations undoubtedly show the existence of glass ceilings in this area. The fact that women are discriminated concerning working position and the height of earning, irrespective of the level of education is proved by numerous domestic works and studies as well as the quantitative indicators of the Statistical Office of the Republic of Serbia. The goal of this paper is to confirm the gender inequality in the hotel industry of the northern Serbian province Vojvodina by using the qualitative indicators, stating attitudes, opinions and feelings. The structured interview was used as a basic method for gathering data. It was designed for women on the positions of medium and operative management, employed in ten representative hotels of Vojvodina. There is basic hypotheses about the existence of glass ceiling phenomena. The results of these interviews confirm previous quantitative indicators, as well as the basic hypothesis and most of the additional hypotheses.
\end{abstract}

Keywords gender inequality, glass ceilings, qualitative indicators, interview, Vojvodina (Northern Serbia).

\section{INTRODUCTION}

The tourism industry is one of the world's largest industries and one of the fastest growing contributing five percent of the world's GDP and seven percent of the world's jobs [1]. Part of that growing tourism industry is the hotel sector which was forecasted to reach $\$ 550$ billion USD globally in 2016 [2], [3]. Within this changing and challenging environment, changes in the workforce and employability are evident and required. Amongst other factors such as geographical and cultural distances [4], the increasing numbers of women in employment have changed the face of hospitality organizations.

According to the [5], over 200 million people are employed in the hospitality and tourism industry, and women represent $55.5 \%$ [6]. Nevertheless, there are few women found in high managerial positions [7] and only in the last decade, women were allowed to climb the managerial ladder [8], [9]. The number of women in senior management roles in the hotel industry is low as only 19.93 percent of executive positions in International Hotel Groups were women in 2012 [3]. So even though women hold over 60 percent of the world's positions in the services sector, they are not reaching the executive positions [10]. The tourism sector, namely at the management level, presents specific characteristics that work as an impediment to women's career progression. Long working hours, demands for geographical mobility, and a persisting male corporate culture are some of the most important pillars that support the 'glass ceiling' that hinders women's careers in the sector [11].

Organisations are influenced by constant gendering processes, i.e. formal and informal practices and policies that seem to be 'gender-neutral' at the surface level, but that affect men and women differently [12]. Thus, gender inequality still prevails in organisational practices, despite a dominant perception of equality [13].

Organizations in a patriarchal society show "hegemonic masculinity" that refers to practices that legitimate the power of men over women [14]. Under these conditions, women are always in the position of being outsiders, of being "travelers in a male world" [15]. Additionally, it has been argued that women in certain situations adopt appropriate 
behaviors and roles adapted to the context in which they operate [16]. In other situations, women have the opportunity to express themselves and operate according to their traditional roles [17], [18]. Hence, as [19] and [20] suggested, the hospitality and tourism industry are influenced by gender stereotyping and therefore, there are certain types of work that women can do. They continued that women are mainly found in part-time or seasonal jobs in tourism. There are certain positions that are dominated by women and others by men. Still, women in this case hold positions that would not allow them to progress in the hierarchy and become hotel general managers [21], [16] or hold those that are poorly paid [19].

Some of the major factors that prevent women from attaining the "C" level have been identified as: counterproductive behavior of male coworkers; inhospitable corporate culture; lack of careful career planning and planned job assignments; lack of mentoring; poor opportunities from managers; social exclusion (being ostracized from informal networks of communication); and stereotyping and preconceptions [22]. Baum found that the long working hours, seasonality and distances to work found in the hospitality industry impose barriers for women with family responsibilities [6]. However other research indicates that barriers are selfimposed and involve family and household responsibilities [22], [23].

Whilst female representation at lower and middle management is on the increase, the trend is not the same at the senior management level [24]. The under representation of women at senior management has been attributed to what several authors have termed the "glass ceiling". The concept of the "glass ceiling" emanated from corporate US where a commission termed the Glass Ceiling Commission was set up to investigate why the involvement of women in employment in the USA was not in proportion to their representation at senior management.

The glass ceiling has been described as an invisible barrier akin to a concrete ceiling that is impenetrable and prevents the accession of women to seni $r$ levels of management. The way the glass ceiling manifests itself differs between countries and organizations. How the glass ceiling is managed will determine the success of an equitable workplace [25], [26], [27].

Wahl claimed that many studies approaching women in management focus on the individual level (i.e. women's characteristics, background or level of 'femininity'), instead of addressing organizational and societal structures [28]. These studies fail to acknowledge the wider conditions that women face in the organization and in the society. He also noted that when women are in a minority position, they are described as lacking leadership qualities [29]. However, when there are more women in the management group, women's competences are reinforced as legitimate. Hearn also underlined the importance of having a critical mass of women to break the cycle of homosocial reproduction and cultural cloning [30]. This way, the masculine model of lifetime, full-time and continuous employment, which is still central and assumed as the norm, can be challenged [31].

$\mathrm{Ng}$ and Pine discovered that segregation of women in the hotel industry occurs horizontally where the jobs mainly held by women include housekeeping, sales and human resources, which are traditionally not jobs that lead to upper management.

Careers in hotels are mainly linear and one moves through the positions of front line, to supervisor, to assistant manager to manager to executive manager [32]. The segregation of women in the hotel industry is also vertical in that not many women reach the upper management or executive position in the hotel industry.

The reasons for this lack of women in executive positions in the hotel industry includes the "Old Boys Network", family commitments, lack of required experience and no female role models [22], [33]. There is ample research on the barriers that women face in their careers and include lack of networking, few mentors, wage gaps, and stereotyping [34], [35], [36], [37], [38]. Also, there is a wage disparity between men and women in the hotel industry as women earn $81 \%$ of men's salaries [36], [39]. It appears that the hotel industry needs to implement more gender equality practices to attract and retain this important pool of talent.

Modern society in the United States is often characterized as highly democratic, humanistic, and advanced. At the same time, arguments concerning the real equality of all people regardless of their race, gender, or social position, still persist. Arguments concerning the position of females in modern society are among the most contradictive. There are people who sincerely believe that women have managed to get an equal position in society compared to men and that women have real equal opportunities as men do

However, there are other people with a totally different view on the position of women in modern society. According to them, the glass ceiling still remains an unsurpassable barrier woman regularly face in their life [40]. All women around the world in some stage of their life career need to break the "glass ceiling" to achieve their career goals. The ceiling is located above the lowest middle-level management positions and prevents women from attaining higher management positions. Thus, the 
glass ceiling describes an organizational level beyond which female managers are not promoted even though they are as qualified as their male counterparts [41]. The goal of this paper is to

\section{METHODOLOGY}

The primary data for this research was gathered through fieldwork and alluded direct conversation - structured interview, which is considered as one of the most frequently used techniques in qualitative researches [11]. Following the research nature of this study, ten structured interviews were done with female managers in the touristic economy of Vojvodina. The interviews included

\section{FINDINGS}

The interview about gender equality in the hotel economy of Vojvodina was intended for women positioned as high, medium and operational management to find out about the problems of gender equality. Ten women with high education, from 27 to 50 years of age and with 5-25 years of working experience participated in the research. Because of their protection, the objects where they are employed are denoted with the alphabet letters. The examinees mostly gave the same answer for the first several questions, denying gender inequality. But further analysis of the answers shows the opposite. Under the term of gender equality, $40 \%$ of examinees consider equal rights and commitments in business, $30 \%$ adds to the previous answer or specifically refers about equal earning for the same job, $50 \%$ thinks that it is the equality of men and women or equal possibility for promotion and affirmation in social-political system. When it comes to presence in managing positions, $40 \%$ think that those positions are exclusively for men. Even though most examinees think that gender is not important for working in the hotel industry and that gender is not considered when employing new worker, in continuance they confirm certain prejudices and stereotypes, so from the context you can conclude that $80 \%$ examinees think that certain jobs are for men (waiter, carpenter, locksmith, electrician, chauffeur, security), while others are just for women (cook, maid, hotel hostess, cleaning lady, receptionist).

The question of earning is very sensitive, so that is not a common subject and it is regulated with the intern rulebook within companies. The greater majority think that salaries are equal in the same

\section{CONCLUSION}

Even though numerous researches have shown gender inequality, when it comes to the genderrelated division of earning in hospitality sector [42], [43], [44], [45], [16], it didn't prove as correct in our confirm the problem of the "glass ceiling" in the hotel industry of the northern Serbian province Vojvodina by using the qualitative indicators, stating attitudes, opinions and feelings.

different levels of management: medium $(n=5)$ and operational management $(n=5)$.

The interview was held from May, the 1st until June, the 31st 2019 and included 10 representative hotels of Vojvodina. Based on the analysis of domestic and foreign literature, we stated this hypothesis: the problem of the "glass ceiling" exists in the hotel economy of Vojvodina.

positions without regard to gender $(90 \%)$. When it comes to mobbing, discrimination or harassment in the workplace, the answers were divided so that the majority of $70 \%$ examinees say they did not have such experiences.

When it comes to adjusting the work time with family or private commitments, bringing work home and the impression that those commitments suffer because of work, 70\% examinees answered that family and their private life suffer because of work and discrepancy between work and family time. Only $30 \%$ of examinees said that they had to invest more effort than their male colleagues to get to their positions.

Opposite to the previous answer, $70 \%$ of female managers think that they had to give up their spare time, family life and even starting a family to advance in their careers. Besides, $75 \%$ examinees stated that there was some kind of obstacle in their advancing. It is indicative that $25 \%$ of them said that the obstacle was their physical appearance.

As a source of support, the examinees brought up their family $(60 \%)$, colleagues and co-workers $(50 \%)$ and managers only $30 \%$, but still $50 \%$ didn't become a parent which is an indicative sign of giving up because of the career.

In $100 \%$ cases, it has been confirmed that maternity leave in companies is only taken by women, even though men also have a legal right on it. From all the examinees who were pregnant, $80 \%$ answered that being pregnant didn't influence on advancing in their career, while in $20 \%$ there were great troubles and turbulences. In the end, 70\% examinees consider that the position of women and men in the economy is not equal.

research. The quantitive indicators [46] show that the gap between the salaries of highly educated men and women in the hotel industry of Vojvodina has almost disappeared. This can be seen in the answers 
of the examinees employed on medium and low managing positions in the hotels in Vojvodina, where only one examinee $(10 \%)$ thinks that men and women in the same positions are not equally paid. Yet, as the goal of this paper was to question the qualitative indicators of gender inequality of those who are employed on different levels of management, in continuance we will give conclusions about the stated hypothesis and percentage of gender-sensitive answers related to the presence in one of two levels of management.

We can conclude that gender inequality exists in the hotel economy of Vojvodina. Even $80 \%$ of the examinees, directly or indirectly considers that certain jobs are only for men (waiter, carpenter, locksmith, electrician, chauffeur, security), while others are just for women (cook, maid, hotel hostess, cleaning lady, receptionist) and that it the case because of "the nature of business". However, modern society should be free from these prejudices to which belongs the belief that women are not equally good managers. Then, there exists the sense of discrimination and mobbing is expressed in relation to gender, because $30 \%$ of examinees consider that they experience the feeling of genderbased discrimination or mobbing. In addition, there is also an opinion that the business and private spheres are not adjusted, because $70 \%$ of examinees confirmes that the working hours are not adjusted with private life, that alludes working in shifts, at the weekend and overtime, then bringing work home and being available 24 hours so that family is often neglected. Besides the fact that numerous examinees stated that there is now an equal division between home and family commitments, this problem of working overtime or from home after regular work is becoming serious. Furthermore, there is an opinion that the business position of women and men is not equal, because it was confirmed by $80 \%$ of examinees who think that men are favored and that they have more business possibilities than women.

Before bringing up the conclusion about hypothesis, we should say that the differentiation according to the level of management brings certain differences in case of gender sensitivity or gender endangerment. The examined members of medium management gave such answers where we could talk about gender inequality in three of five. This means that in the line of medium management there is a feeling of gender inequality. In the first line of management, four out of five examinees confirm the existence of gender inequality, which confirm the rule that the gender inequality grows with the decrease of work and educative position. Related to previous facts, hypothesis that the problem of "glass ceiling"is present in the hotel industry of Vojvodina can be accepted. It can't be clearly quantitatively expressed, but there are qualitative indicators like attitudes, opinions and feelings of interviewed managers about gender inequality, so in future we should work on removing all the facts that produce this kind of attitudes, opinions and feelings, so that in all working positions and levels of management we could have the same working conditions, without regard to gender.

\section{REFERENCES}

[1] UNWTO, International Tourism Highlights, Edition (2011).

[2] Hospitality Net, The Global Hotel Industry and Trends for 2016, Industiy News, 18 December, Available at: http://hospitalitynet.org/news/4073336.html.

[3] Blayney, C., \& Blotnicky, K. Women's representation in the hotel industry, International Journal of Management and Human Resources, 1(1), 10-28, (2013).

[4] Nickson, D., \& Warhust, C. From globalization to internationalization to Americanization: The example of "little Americas" in the hotel sector. In M. Hughes, \& J. Taggart (Eds.), Multinationals in a new era - International strategy and management (pp. 207-225). Basingstoke: Palgrave, (2001).

[5] International Labour Office [ILO]. Facts on the hotel and catering industry, (2009). http://www.ilo.org/communication

[6] Baum, T. International perspectives on women and work in hotels, catering, and tourism. Geneva: International Labor Organization, (2013).

[7] Li, L., \& Leung, R. W. Female managers in Asian hotels: Profile and career challenges. International Journal of Contemporary Hospitality Management, 13(4), 189-196, (2001).

[8] Mavridis, D. Cherchez la Femme-Women as managers in Greek corporates: An empirical investigation, Equal Opportunities International, 21(7), 21-36, (2002).

[9] Catalyst, Catalyst census: Fortune 500 women executive officers and top earners, August 2013 at http://www.catalyst.org/knowledge/2013-catalyst-census-fortune-500-women-executive-officers-and-top-earners 
[10] Catalyst, The bottom line: Corporate performance and women's representation on boards, August 2017 from http://www.catalyst.org/knowledge/bottom-line-corporate-performance-and-womens-representationboardsHospitalitynet (2015). The global hotel industry and trends for 2016 found August 2017 at https://www.hospitalitynet.org/ news/4073336.html

[11] Carvalho, I., Costa, C., Lykke, N. \& Torres, A. Women sitting on the glass roof: Critical perspectives on the tourism sector, Revista Turismo e Desenvolvimento, 21/22 (5): 35-37, (2014).

[12] Hearn, J. On the Complexity of Feminist Intervention in Organisations, Organisation, 7(4), 609-624, (2000).

[13] Benschop, Y., \& Doorewaard, H. Covered by equality: The gender subtext of organisations. Organisation Studies, 19(5), 787-805, (1998).

[14] Thomas, A. B. Controversies in management, issues, debates, answers (2nd ed.). New York, N.Y.: Routledge/Taylor \& Francis Group, (2005).

[15] Marshall, J. Women managers: Travellers in a male world. Chichester: John Wiley \& Sons, (1984).

[16] Biswas, R. and Cassell, C. Strategic HRM and the Gendered Division of Labour in the Hotel Industry: A Case Study. Personnel Review, 25(2), 19-34, (1996).

[17] Brownell, J. Women in hospitality management: General managers' perceptions of factors related to career development. International Journal of Hospitality Management, 13(2), 101-117, (1994a).

[18] Brownell, J. Personality and career development: A study of gender differences. Cornell Hotel and Restaurant Administration Quarterly, 35(2), 36-43, (1994b).

[19] Kinnaird, V., \& Hall, D. Tourism: A gender analysis. Chichester: John Wiley \& Sons, (1994).

[20] Jordan, F. An occupational hazard? Sex segregation in tourism employment, Tourism Management, 18(8), 525-534, (1997).

[21] Woods, R. H., \& Viehland, D. Women in hotel management. Cornell Hotel and Restaurant Administration Quarterly, 41(5), 51-54, (2000).

[22] Boone, J., Veller, T., Nikolaeva, K., Keith, M., Kefgen, K., \& Houran, J. Rethinking a glass ceiling in the hospitality industry, Cornell Hospitality Quarterly, 54(3), 230-239, (2013).

[23] Garcia-Pozo, A., Marchante-Mera, A., \& Sanchez-Ollero, J. Occupational differences in the return on human capital in the Spanish travel agency and hospitality industries, Tourism Economics, 17(6), 1325-1345, (2011).

[24] Bazazo, I., Nasseef, M., Mukattesh, B., Kastero, D. \& Al-Hallaq, M. Assessing the Glass Ceiling Effect for Women in Tourism and Hospitality, Journal of Management and Strategy, 8(3): 51-66, (2017).

[25] Tohmé, A. Women, Intangible Heritage and Development in the Arab World. United Nations Educational, Scientific and Cultural Organization, 1-32, (2001).

[26] Badarin, R., \& Qawasmeh, F. Role of Women in Leading Change: Applied Study on Working Women Organizations in Jordan, Al-Balqa for Research and Studies, 16(1), 17-57, (2012).

[27] Kiaye, R., \& Singh, A. The Glass Ceiling: A Perspective of Women Working in Durban. Gender in Management: An International Journal, 28(1), 28-42, (2013). https://doi.org/10.1108/17542411311301556

[28] Wahl, A. Könsstrukturer i organisationer, Kvinnliga civilekonomers och civilingenjörers karriärutveckling, Lund: Studentlitteratur, (2003).

[29] Wahl, A. From lack to surplus. In S.-E. Sjöstrand, J. Sandberg \& M. Tyrstrup (Eds.), Invisible Management, The Social Construction of Leadership (pp. 126-148). London: Thomson, (2001).

[30] Hearn, J. Equality, growth, sustainability: Adding some more missing ingredients to the mixture. Paper presented at the Equality, Growth and Sustainability - Do they mix?, Linköping, (2010).

[31] Collinson, D. L., \& Hearn, J. Men and Masculinities in Work, Organisations, and Management, In M. Kimmel, J. Hearn \& R. W. Connell (Eds.), Handbook of Studies on Men \& Masculinities (pp. 289-310). Thousand Oaks: Sage, (2005).

[32] Ng, C., \& Pine, R. Women and men in hotel management in Hong Kong: Perceptions of gender and career development issues, Hospitality Management, 22(1), 85-102, (2003).

[33] Mooney, S. Children and a career: Yeah right! Barriers to women managers' career progression in hotels, New Zealand Journal of Human Resources Management, 9(3), 151-161, (2009). 
[34] Burgess, C. Hotel accounts - do men get the best jobs? International Journal of Hospitality Management, 19(4), 345$352,(2000)$.

[35] Diehl, A., \& Dzubinski, L. Making the invisible visible: A cross-sector analysis of gender-based leadership barriers. Human Resource Development Quarterly, 27(2), 181-206, (2016).

[36] Eagly, A., \& Carli, L. Through the labyrinth, the truth about how women become leaders. Boston, Mass: Harvard Business School Press Book, (2007).

[37] Fisher, A. When will women get to the top?, Fortune 125, 44-56, (1992).

[38] Stainback, K., Kleiner, S., \& Skaggs, S. Women in power: Undoing or redoing the gendered organization. Gender \& Society, 30(1), 109-135, (2016).

[39] Santero-Sanchez, R., Segovia-Perez, M., Castro-Nunez, B., Figueroa-Domecq, C., \& Talon-Ballestero, P. Gender differences in the hospitality industry: A job quality index, Tourism Management, 51, 234-246, (2015).

[40] Clevenger, L., \& Singh, N. Exploring Barriers That Lead to the Glass Ceiling Effect for Women in the U.S. Hospitality Industry, Journal of Human Resources in Hospitality \& Tourism, 12, 376-399, (2013).

[41] Pollard, P. L. A Critical Analysis of Gender-based Workplace Challenges Facing Women: Gender and Compensation, Forum on Public Policy: A Journal of the Oxford Round Table, (2007).

[42] Evers, A. i Sieverding, M. Why do Highly Qualified Women (Still) Earn Less? Gender Differences in Long-Term Predictors of Career Success. Psychology of Women Quarterly, 38, 93-106, (2014).

[43] Gibelman, M. Progress or complacency?, Pay equity for Women Circa 2001. Affilia, 17 (3), 279-298, (2002).

[44] Sparrowe, R.T., Iverson, K.M., Cracks in the glass ceiling? An empirical study of gender diferences in income in the hospitality industry, Journal of Hospitality and Tourism Research, 23(1), 4-20, (1999).

[45] Purcell, K. The relationship between career and job opportunities: women's

employment in the hospitality industry as a microcosm of women's employment, Women In Management Review, 11(5), 17-24, (1996).

[46] Garača, V., Vukosav, S., Curaković, D., Bradić, M., Banjac, M, The salaries of employees in tourism industry of Vojvodina (Serbia) as a gender inequality indicator, International Scientific Conference GEOBALCANICA 2019, Sofia, Bulgaria, 2019, 491-500. 